\begin{tabular}{|c|l|}
\hline Title & Water-soluble characteristics of chlorine in char derived from municipal solid wastes \\
\hline Author(s) & Hwang, I.H.; Matsuto, T.; T anaka, N. \\
\hline Citation & $\begin{array}{l}\text { Waste Management, 26(6), 571-579 } \\
\text { https://doi.org/10.1016/.wasman.2005.04.012 }\end{array}$ \\
\hline Issue Date & 2006 \\
\hline Doc URL & http://hdl.handle.net/2115/13479 \\
\hline Type & article(author version) \\
\hline File Information & WM_26(6)_571-.pdf \\
\hline
\end{tabular}

Instructions for use 


\title{
Water-soluble characteristics of chlorine in char derived from municipal solid wastes
}

\author{
I.H. Hwang, T. Matsuto*, and N. Tanaka \\ Laboratory of Solid Waste Disposal Engineering \\ Graduate School of Engineering \\ Hokkaido University \\ Kita 13, Nishi 8, Kita-ku \\ Sapporo 060-8628, Japan
}

*Corresponding author. Tel./fax: +81-11-706-6827.

E-mail address: matsuto@eng.hokudai.ac.jp (T. Matsuto). 


\section{Abstract}

Chlorine in char derived from municipal solid waste (MSW) was characterized and quantified based on its water solubility: easily water-soluble, hardly water-soluble, and non water-soluble chlorine. For that, a four-cycle process of water-washing, heating or carbonation was carried out. In order to confirm the characteristics of non water-soluble chlorine, additional thermal treatment and an alkali-acid washing process were applied to washed char. It was found that a large particle size of char $(0.5$ to $1.0 \mathrm{~mm})$ significantly contributed to the amount of non water-soluble chlorine. Pulverization and $\mathrm{HNO}_{3}-\mathrm{HF}$ digestion were performed to identify a factor to interfere chlorine release from char with a large particle size. Pulverization was proven ineffective for release of non water-soluble chlorine, whereas approximately $32 \%$ of non water-soluble chlorine was extracted by $\mathrm{HNO}_{3}$-HF digestion. Therefore, the presence of non water-soluble chlorine is likely to originate from its chemical property rather than simply from its physical one.

Key words: Char; Pyrolysis; Municipal solid waste; Chlorine; Water-solubility; Washing; Carbonation 


\section{Introduction}

Recently, many countries have adopted a proactive policy on energy or resource recovery from MSW to cope with the lack of natural resources as well as to minimize environmental impacts. According to the literature, experts have predicted that up to 5\% of Europe's domestic electricity might be supplied by means of MSW combustion (Vassilev et al., 1999a). However, MSW incinerators have a weakness compared with common coal-fired power plants because of significant lower energy efficiencies (13 to 14\%) due to lower steam temperature to prevent severe boiler corrosion, fouling, and slagging (Malkow, 2004). On the other hand, char has many advantages as fuel in comparison to MSW from a WTE (Waste-To-Energy) point of view because it is of higher quality and is easier to handle. Nevertheless, in contrast to natural fossil fuels, the presence of a relatively high content of unfavorable components, such as chlorine or ash, is inevitable due to the fact it is originally derived from refuse.

To say nothing of $\mathrm{HCl}$ or dioxin generation, chlorine may cause serious corrosion or fouling problems during combustion when its content exceeds $0.3 \mathrm{wt} \%$ of fuel (Chen and Pagano, 1986). In most cases, chlorine plays a role in facilitating mobility of alkali as a form of salts (Jenkins et al., 1998). In particular, potassium chloride is one of the most stable high-temperature, gas-phase, alkali-containing species. It reacts with sulfur or silica and then forms low melting point of sulfate or silicate (Arvelakis and Koukios, 2002). These may harm components of a thermochemical conversion system such as a heat exchanger, gas-turbine blades, and other power system components (Ban et al., 1998). 
Vassilev et al. (1999a) noted that the major sources of chlorine in char derived from refuse are PVC, other chlorine-based plastics, chlorinated paper, and food remains. They also categorized the occurrence of chlorine in char as follows: (1) the slightly changed organic material and char component, (2) the fused $\left(667\right.$ to $\left.801{ }^{\circ} \mathrm{C}\right) \mathrm{K}, \mathrm{Na}, \mathrm{Mg}, \mathrm{Ca}$ and $\mathrm{Fe}$ chlorides, and (3) the absorbed $\mathrm{Cl}$ in pore moisture onto and into the organic and mineral phases (Vassilev et al., 1999b).

Many studies about biomass or coal cleaning have shown that a large portion of the chlorine could be released by water-washing (Chen and Pagano, 1986; Jenkins et al., 1998; Jensen et al., 2001). Jensen et al. (2001) reported that $90 \%$ of the chlorine was released from biomass char within 20 min by washing. Chen and Pagano (1986) found that a high chlorine coal $(0.5 \mathrm{wt} \%)$ could meet the chlorine design criterion of $0.2 \mathrm{wt} \%$ of coal by application of a high temperature $\left(93.7^{\circ} \mathrm{C}\right)$ leaching technique.

Nevertheless, in most cases, it was reported that some amount of chlorine still remained in the coal or char after the water-washing procedure. Huggins and Huffman (1995) pointed out that chloride anions are preferentially located in the smallest micropores rather than in meso- or macropores of coal. This causes a slow and incomplete aqueous leaching of chlorine from coal in short-term experiments. They discussed that chlorine anions in pore moisture might be strongly anchored to the surface of micropores in coal macerals by organic ionic complexes, such as quaternary amine groups and alkali carboxyl complexes (Huggins and Huffman, 1995). On the other hand, chlorine compounds in char might react with some metal groups or insoluble compounds during pyrolysis and then transform poorly soluble chlorides or stable complex salts such as $3 \mathrm{CaO} \cdot \mathrm{Al}_{2} \mathrm{O}_{3} \cdot \mathrm{CaCl}_{2} \cdot 10 \mathrm{H}_{2} \mathrm{O}$, which is known as a Friedel's salt. However, the stability 
of Friedel's salt is $\mathrm{pH}$ dependent, that is, if the $\mathrm{pH}$ falls, for example, due to carbonation or pozzolanic mineral additions, the dissolution of Friedel's salt is accelerated and freechlorine is liberated (Suryavanashi and Swamy, 1996; Goňi and Guerrero, 2003). In addition to the above configurations, certain chlorine compounds may exist as insoluble forms in char with vagueness.

A water-washing process can be a simple but practical method for chlorine removal. However, all chlorine compounds are not dissolved well in water, so additional removal techniques may be required to satisfy a criterion of chlorine content in char depending on its intended use. Nevertheless, there is no doubt that it is preferable to avoid excessive chemical addition or energy input as much as possible. Therefore, it is essential not only to understand the solubility of chlorine compounds in water but also to determine a proper method for chlorine removal. The objective of this study is to determine chlorine in char derived from MSW, preferentially based on solubility in water.

\section{Material and Methods}

\subsection{Material}

The pyrolysis-melting facility located at M city in Hokkaido has a capacity to treat $210 \mathrm{t} / \mathrm{yr}$ of MSW excluding recyclable or non-combustible waste. Shredded waste is pyrolyzed in a rotary kiln at $450^{\circ} \mathrm{C}$ for $1 \mathrm{hr}$ in a nitrogen atmosphere. Char is cooled and separated successively by a sieve, a magnetic separator and a vertical air classifier. After

that, the char is stored in a hopper to feed into a melting process. Around $5 \mathrm{~kg}$ of char 
was sampled from the hopper and passed through 100 mesh (more than $99 \mathrm{wt} \%$ of raw char) was prepared as a representative sample. Figure 1 shows a cumulative particle size distribution of char.

\subsection{Determination of chlorine in char based on water-solubility}

Around $100 \mathrm{~g}$ of char was immersed in a $5 \mathrm{~L}$ flask containing $1 \mathrm{~L}$ of distilled water. The flask was shaken at $150 \mathrm{rpm}$ for $20 \mathrm{~min}$ and then the solution was filtered using $1 \mu \mathrm{m}$ pore size filter paper. The entire procedure was repeated up to four times to allow chlorine to dissolve fully in distilled water. Chlorine released by four cycles of washingfiltration was referred to as easily water-soluble chlorine $\left(C l_{\mathrm{EW}}\right)$ in this work.

As a next step, either carbonation or heating was performed to identify and to quantify chlorine existing in the form of difficult-to-dissolve chlorides that remained in the char after the water-washing process. As already mentioned, if poorly soluble chlorides such as Friedel's salt are present in char, carbonation will contribute to their release. On the other hand, heating was conducted not only to evaporate condensed water from the pore structure but also to improve the solubility of difficult-to-dissolve chlorides at a higher temperature. Under the assumption that chlorine anions in pore water are strongly associated with the inner surface of the micropore by some organic ionic complexes (Huggins and Huffman, 1995), chlorine ions come to lose their coherence with organic complexes if condensed water in the pore structure is evaporated by heating. Liberated free chlorine ions are expected to be released easily from char during the rewashing procedure. Carbonation and heating was carried out as follows: 
- Carbon dioxide direct contact and rewashing (Method I): $5 \mathrm{~g}$ of washed char was put into a $300 \mathrm{ml}$ flask. The flask was filled with pure carbon dioxide for $5 \mathrm{~min}$ at a flow rate of $100 \mathrm{ml} / \mathrm{min}$ and then kept for 3 to $24 \mathrm{hr}$. After that, it was shaken in $50 \mathrm{ml}$ of distilled water at $150 \mathrm{rpm}$ for $20 \mathrm{~min}$.

- Carbon dioxide bubbling and stirring (Method II): $5 \mathrm{~g}$ of washed char was soaked in $50 \mathrm{ml}$ distilled water and agitated by a magnetic stirrer under bubbling with pure carbon dioxide at a flow rate of $25 \mathrm{ml} / \mathrm{min}$ for $5 \mathrm{~min}$ to $3 \mathrm{hr}$.

- Heating and rewashing (Method III): $5 \mathrm{~g}$ of washed char was heated using a dry furnace set at $80^{\circ} \mathrm{C}$ for $5 \mathrm{~min}$ to $24 \mathrm{hr}$ and cooled in a desiccator. The moisture content of the washed char was measured before and after heating. The char was shaken in $50 \mathrm{ml}$ of distilled water at $150 \mathrm{rpm}$ for $20 \mathrm{~min}$.

After these procedures, char and filtrate were separated using $1 \mu \mathrm{m}$ pore size filter paper. Chlorine in the filtrate was classified as hardly water-soluble chlorine $\left(\mathrm{Cl}_{\mathrm{HW}}\right)$, whereas chlorine remaining in the char was classified as non water-soluble chlorine $\left(C l_{\mathrm{NW}}\right)$. Figure 2 shows an experimental flow for determination of chlorine in char based on water-solubility.

\subsection{Investigation of characteristics of non water-soluble chlorine}

It was reported that chlorine-containing plastics contribute 50 to $70 \%$ of the chlorine in MSW (Vassilev et al., 1999a). Generally, a two-stage process may account for the pyrolytic degradation of PVC (Miranda et al., 1999): (1) a stage in the temperature range of 200 to $360^{\circ} \mathrm{C}$ (dehydrochlorination reaction and polyene formation), and (2) 
another stage occurring in the range of 360 to $500^{\circ} \mathrm{C}$ (degradation of polyene). However, some chlorine might remain in char as a form of incompletely decomposed plastic or resin component in spite of pyrolysis at $450^{\circ} \mathrm{C}$. Consequently, most of them may be classified as non water-soluble chlorine in this work. Thus, additional thermal treatment was carried out at $500^{\circ} \mathrm{C}$, assuming the degradation of plastics including PVC is completed at $500^{\circ} \mathrm{C}$. First, a sample boat containing around $1 \mathrm{~g}$ of char was placed in a quartz tube reactor. It was heated to $500^{\circ} \mathrm{C}$ at a heating rate of $15^{\circ} \mathrm{C} / \mathrm{min}$ under nitrogen atmosphere and then maintained at that temperature for $30 \mathrm{~min}$. The variation of chlorine content in char was measured before and after thermal treatment.

A pH-controlled washing process was performed to investigate whether or not non water-soluble chlorine could be extracted by alkali or acid solution. Around $5 \mathrm{~g}$ of dried char after water-washing was soaked in $50 \mathrm{~mL}$ of $\mathrm{pH}$ adjusted water and agitated by a magnetic stirrer for 20 min. $\mathrm{pH}$ adjustment was done by $0.1,0.5$, and $1 \mathrm{M}$ of $\mathrm{HNO}_{3}$ or $\mathrm{NaOH}$ solution. After filtration, char on filter paper was rinsed with $50 \mathrm{~mL}$ of distilled water to remove chlorine adhering to the surface of the char. Both filtrate and rinsing water were collected to measure chlorine concentration.

To investigate non water-soluble chlorine distribution depending on particle size, the char was classified into three fractions (Figure 1): (1) small $(<0.125 \mathrm{~mm}$ ), (2) medium (0.125 to $0.5 \mathrm{~mm})$, and (3) large (0.5 to $1.0 \mathrm{~mm})$. Each size fraction of char was used to estimate total chlorine content and proximate analysis. Easily water-soluble, hardly water-soluble, and non water-soluble chlorine in different particle sizes of char were determined. 
Finally, either pulverization or $\mathrm{HNO}_{3}-\mathrm{HF}$ digestion treatment was conducted to identify a hindrance factor to chlorine release using the large particle size fraction of char. Pulverization was executed to identify whether or not chlorine trapped in particles could be released physically. For this purpose, around $50 \mathrm{~g}$ of char was pulverized in a ball mill for $1 \mathrm{hr}$. The variation of chlorine distribution based on water solubility was investigated before and after milling. $\mathrm{HNO}_{3}$-HF digestion was chosen to extract chlorine chemically by breaking the matrix of organic matter and of ash that may enclose chlorine compounds. First, $5 \mathrm{ml}$ of $\mathrm{HNO}_{3}$ and $20 \mathrm{ml}$ of $\mathrm{HF}$ were added to $1 \mathrm{~g}$ of char contained in a $100 \mathrm{ml}$ Teflon beaker with a cap and then heated at $120^{\circ} \mathrm{C}$ for $24 \mathrm{hr}$ on a hot plate. This was evaporated and cooled at room temperature. Then $5.6 \mathrm{~g}$ of boric acid and $20 \mathrm{ml}$ of $3 \mathrm{~N}$ $\mathrm{HNO}_{3}$ were added and evaporated at $80^{\circ} \mathrm{C}$ for $30 \mathrm{~min}$. After cooling, this was filtered and filtrate was adjusted volume to $60 \mathrm{ml}$. This was prepared to measure chlorine concentration.

\subsection{Analytical methods}

\subsubsection{Measurement of chlorine content in solid}

In order to estimate chlorine content in solid, the JIS Z 7302-6 method was carried out using an electric furnace and a quartz tube reactor. Around $1 \mathrm{~g}$ of char was placed on a sample boat and loaded into a tubular reactor. It was heated to $800^{\circ} \mathrm{C}$ at a heating rate of $15^{\circ} \mathrm{C} / \mathrm{min}$ and then kept at that temperature for $30 \mathrm{~min}$. Pure oxygen was used for complete combustion at a flow rate of $0.2 \mathrm{~L} / \mathrm{min}$. The existing JIS method (JIS Z 7302-6) mandates measurement of chlorine just collected in gas scrubbing bottles. Watanabe et al. 
(2003) noted that the result obtained by the above method showed a lower value than that by the bomb or crucible method, because a significant amount of chlorine remained in residue itself or adsorbed at the inner surface of the quartz tube in the form of metal salts.

Based on the above observation, the amount of "volatile chlorine" was determined by the summation of chlorine dissolved in scrubbing water and adhered to the tubular reactor wall in this work. The latter was collected by a thorough flushing with $50 \mathrm{ml}$ of $20 \%$ nitric acid. Meanwhile, $50 \mathrm{ml}$ of $20 \%$ nitric acid was added to the combustion residue and was heated at $100^{\circ} \mathrm{C}$ for $1 \mathrm{hr}$ in order to extract the chlorine fixed in the residue. After filtering by $1 \mu \mathrm{m}$ pore size filter paper, chlorine in the filtrate was measured as "residual chlorine". Consequently, chlorine content in the solids was determined by the sum of volatile and residual chlorine. Prior to measuring the chlorine content of char, the precision of the JIS method for chlorine analysis was evaluated. The mixture of polyvinylchloride and sodium chloride ( $\mathrm{PVC}: \mathrm{NaCl}=1: 1)$ was used as a reference sample. The chlorine recovery rate was 96 to $101 \%$ by the modified JIS method, whereas it was just nothing but 50 to $58 \%$ by the existing JIS method (Table 1).

\subsubsection{Measurement of chlorine in aqueous solution}

The mercuric thiocyanate method was introduced to measure chlorine concentration in aqueous solution (JIS K0107); $2 \mathrm{ml}$ of ammonium ferric sulfate solution, $1 \mathrm{ml}$ of mercuric thiocyanate solution, and $10 \mathrm{ml}$ of methanol was added to a $5 \mathrm{ml}$ sample. The sample was analyzed by spectrophotometer (Hitachi U-1101) at a wavelength of $460 \mathrm{~nm}$.

\section{Results and Discussion}




\subsection{Chlorine content of char $\left(\mathrm{Cl}_{T}\right)$}

Prior to determination of chlorine based on water-soluble characteristics, the total chlorine content in char was measured by the modified JIS method. As a result, it was estimated to be $14.61 \mathrm{mg} / \mathrm{g}$ char-dry, which was obtained by the summation of 12.79 $\mathrm{mg} / \mathrm{g}$ char-dry of volatile chlorine and $1.82 \mathrm{mg} / \mathrm{g}$ char-dry of residual chlorine.

\section{2 Determination of easily water-soluble chlorine $\left(\mathrm{Cl}_{\mathrm{EW}}\right)$}

Table 2 shows the chlorine content in filtrate released from each step of washing and filtering. Through the entire water-washing process, $12.82 \mathrm{mg} / \mathrm{g}$ char-dry of chlorine was dissolved in distilled water and termed as easily water-soluble chlorine $\left(\mathrm{Cl}_{\mathrm{EW}}\right)$. As presented in Table 2, approximately $85 \%$ of easily water-soluble chlorine was leached out in the first washing procedure; however, chlorine release conspicuously decreased as the number of washing times increased. On the other hand, it was assured that $2.20 \mathrm{mg} / \mathrm{g}$ char-dry of chlorine $\left(C l_{R}\right)$ was still left in the washed char in spite of the repetitive washing and filtering process (Table 2). It included $1.55 \mathrm{mg} / \mathrm{g}$ of volatile chlorine as well as $0.65 \mathrm{mg} / \mathrm{g}$ of residual chlorine. Compared with raw char, it was found that $88 \%$ of volatile chlorine and $64 \%$ of residual chlorine were removed by water-washing.

\subsection{Determination of hardly water-soluble chlorine $\left(\mathrm{Cl}_{\mathrm{HW}}\right)$}


After the water-washing and filtration process, it was found that $2.20 \mathrm{mg} / \mathrm{g}$ char-dry of chlorine $\left(C l_{R}\right)$ was still left in the washed char (Table 2). Three methods (method I to III), namely $\mathrm{CO}_{2}$ direct contact-rewashing, $\mathrm{CO}_{2}$ bubbling-stirring, and heating-rewashing were employed to leach out chlorine remaining in the washed char. As depicted in Figure 3, white plots present released chlorine from char, whereas black ones mean remaining chlorine in the char. The latter was determined by subtracting the chlorine content released using methods I to III from the chlorine content of washed char $\left(C l_{R}\right)$.

The content of released chlorine was proportionate to $\mathrm{CO}_{2}$ contact or bubbling time; however, leaching rate of chlorine by method II $\left(\mathrm{CO}_{2}\right.$ bubbling and stirring) was much faster than that by method I $\left(\mathrm{CO}_{2}\right.$ direct contact and rewashing). While $0.59 \mathrm{mg} / \mathrm{g}$ char-dry of chlorine was released by $24 \mathrm{hr}$ of $\mathrm{CO}_{2}$ contact time in method I (Figure 3(a)), it took merely $2 \mathrm{hr}$ for $0.83 \mathrm{mg} / \mathrm{g}$ char-dry of chlorine to be changed into a soluble form in method II (Figure 3(b)). From the result of method II, chlorine leaching seems to be accelerated by the synergistic effect of mechanical operation, such as bubbling or stirring with carbonation.

On the other hand, it was found that chlorine could be leached by rewashing after heating at $80^{\circ} \mathrm{C}$ (Method III) as shown in Figure 3(c). However, the amount of released chlorine averaged $0.71 \mathrm{mg} / \mathrm{g}$ char-dry when the moisture content was less than $20 \%$. It means chlorine can be released even though $20 \%$ moisture remains in char. Moreover, chlorine release did not increase even when the moisture content reached close to zero. These results do not agree with the initial assumption that chlorine anchored to micropores may be dissociated by evaporation of pore water. Judging from the above result, it is likely that chlorine release was caused by another factor rather than moisture 
evaporation. One of the most possible factors might be carbonation by contact with $0.03 \%$ of carbon dioxide in air. Simultaneously, exposure at high temperature seems to accelerate the rate of transformation of insoluble chlorides into soluble ones. Consequently, 0.59 to $0.83 \mathrm{mg} / \mathrm{g}$ char-dry of chlorine was additionally leached out depending on the experimental condition after removal of easily water-soluble chlorine (Table 3).

The dissolution of above chlorine could not happen by a simple washing using pure water; however, carbonation or heating was likely to be an effective method to promote release of difficult-to-dissolve chlorine compounds without excessive chemicals or energy input.

\subsection{Determination of non water-soluble chlorine $\left(\mathrm{Cl}_{\mathrm{NW}}\right)$}

After removal of easily and hardly water-soluble chlorine, the content of finally remained chlorine in char was measured by the modified JIS method. As a result, approximately $1.68 \mathrm{mg} / \mathrm{g}$ char of chlorine was determined as non water-soluble chlorine $\left(C l_{\mathrm{NW}}\right)$, including $1.07 \mathrm{mg} / \mathrm{g}$ char of volatile chlorine and $0.61 \mathrm{mg} / \mathrm{g}$ char of residual chlorine. Table 4 shows the chlorine balance in char based on water-solubility.

\subsubsection{Identification of non water-soluble chlorine originated from incomplete decomposition of chlorinated plastics}

No significant difference was seen in chlorine content before and after additional thermal treatment at $500^{\circ} \mathrm{C}$ (Table 5). This means that degradable chlorinated compounds 
below $500^{\circ} \mathrm{C}$ were decomposed completely during the carbonization process. At least, non water-soluble chlorine does not seem to originate from partially decomposed forms of chlorinated plastics or resins degradable under $500^{\circ} \mathrm{C}$.

\subsubsection{Determination of chlorine removal by $\mathrm{pH}$-controlled washing}

Figure 4 illustrates that chlorine release increases as the $\mathrm{pH}$ of the aqueous solution decreases. At a pH 1.55, $1.31 \mathrm{mg} / \mathrm{g}$ char-dry of chlorine was extracted from char that was dried for $24 \mathrm{hr}$ at $80^{\circ} \mathrm{C}$ after a repeated water-washing and filtration process. Consequently, the net amount of chlorine dissolved at $\mathrm{pH} 1.55$ corresponds to $0.51 \mathrm{mg} / \mathrm{g}$ char-dry, because around $0.8 \mathrm{mg} / \mathrm{g}$ char-dry of chlorine corresponded to hardly watersoluble chlorine in char.

\subsection{Investigation of chlorine distribution according to particle size}

Table 6 shows the total chlorine content and chlorine distribution of small $(<0.125$ $\mathrm{mm})$, medium ( 0.125 to $0.5 \mathrm{~mm})$, and large $(0.5$ to $1.0 \mathrm{~mm})$ particle sizes of char. As particle size increases, total chlorine content decreases whereas the portion of non watersoluble chlorine conversely increases (Table 6). This means that the amount of non water-soluble chlorine was considerably associated to the large size particle of char and that the large particle fraction of char conclusively contributes to lowering removal efficiency of chlorine by water-washing even though it has the lowest content of total chlorine among the three different sizes of particles. 


\subsection{Influence of pulverization or $\mathrm{HNO}_{3}$-HF digestion on the release of non water-soluble}

chlorine

Supposing chlorine is trapped in the internal side of the particle, its release will be interrupted as the particle size increases. On the other hand, Vassilev et al. (1999a) noted that the most common mineral in char derived from refuse was silicate, which was associated with inorganic matter and was occasionally present as encrustrations on organic matter or in the interstices of coarse particles. Actually, ash content was highest in the large particle size fraction of char in this work, so there is a possibility that such a compound might interfere with dissolution of chlorine (Figure 5).

As a physical method, pulverization was applied to the large particle size fraction $(0.5$ to $1.0 \mathrm{~mm})$ to verify the above assumptions. Table 7 shows the variation of particle size distribution after milling of the large particle size fraction. Table 8 shows the chlorine balance of the large particle size fraction of char before and after milling. However, there is no conclusive evidence that the amount of water-soluble chlorine relatively increased by pulverization. On the other hand, as a chemical method, the digestion method using $\mathrm{HNO}_{3}$ and $\mathrm{HF}$ was applied to the large particle size fraction of

char. As shown in Table 9, chlorine content extracted by $\mathrm{HNO}_{3}-\mathrm{HF}$ digestion averaged $0.82 \mathrm{mg} / \mathrm{g}$ char-dry. It was very difficult to extract all of non water-soluble chlorine, nevertheless around $32 \%$ of the non water-soluble chlorine in $1 \mathrm{~g}$ of large particle size char was leached out by $\mathrm{HNO}_{3}-\mathrm{HF}$ digestion. Therefore, the presence of non watersoluble chlorine is likely to originate from its chemical properties rather than simply physical reasons. 


\section{Conclusions}

In this work, char derived from MSW was examined to characterize and quantify chlorine based on its water solubility. Through a four-cycle washing and filtration procedure, easily water-soluble chlorine was determined by $12.82 \mathrm{mg} / \mathrm{g}$ char-dry. Carbonation or heating was likely to be an effective method to promote releasing hardly water-soluble chlorine without excessive chemicals or energy input. It was found that 0.71 to $0.83 \mathrm{mg} / \mathrm{g}$ char-dry of chlorine could be released from washed char by rewashing after heating at $80^{\circ} \mathrm{C}$ for $30 \mathrm{~min}$ or $\mathrm{CO}_{2}$ bubbling and stirring for $2 \mathrm{hr}$. Non water-soluble chlorine corresponded to $1.68 \mathrm{mg} / \mathrm{g}$ char-dry, which consisted of $1.07 \mathrm{mg} / \mathrm{g}$ char-dry of volatile chlorine and $0.61 \mathrm{mg} / \mathrm{g}$ char-dry of residual chlorine. From above results, it seems that the potential of corrosion or fouling caused by volatile chlorine can be lower as a result of removal of water-soluble chlorine $\left(=C l_{\mathrm{EW}}+C l_{\mathrm{HW}}\right)$. If char is under consideration for use as absorbent or soil conditioner, easily water-soluble chlorine is likely to be removed at least. On the other hand, non water-soluble chlorine does not seem to originate from incomplete thermal treatment at $450^{\circ} \mathrm{C}$; however, around 0.51 $\mathrm{mg} / \mathrm{g}$ char-dry of $C l_{\mathrm{NW}}$ was extracted additionally at a $\mathrm{pH} 1.55$. In addition, it was found that large particle sizes of char ( 0.5 to $1.0 \mathrm{~mm})$ had a significant effect on the amount of non water-soluble chlorine. Pulverization was proven to be ineffective in the dissolution of non water-soluble chlorine whereas approximately $32 \%$ was extracted by $\mathrm{HNO}_{3}$ - $\mathrm{HF}$ treatment. Therefore, the presence of non water-soluble chlorine is likely to originate from its chemical property rather than simply physical one. 


\section{Acknowledgements}

This work was performed with the financial support of Mitsui Engineering \& Shipbuilding Co., Ltd.

\section{References}

Arvelakis, S., Koukios, E.G., 2002. Physicochemical upgrading of agroresidues as feedstocks for energy production via thermochemical conversion methods. Biomass \& Bioenergy, 22, 331-348

Bain, R.L., Overend, R.P., Craig, K.R., 1998. Biomass-fired power generation. Fuel Processing Technology, 54, 1-16

Chen, H.L., Pagano, M., 1986. The removal of chlorine from Illinois coals by high temperature leaching. Fuel processing technology, 13, 261-269

Goňi, S., Guerrero, A., 2003. Accelerated carbonation of Friedel's salt in calcium aluminate cement paste. Cement and Concrete Research, 33, 21-26

Huggins, F.E., Huffman, G.P., 1995. Chlorine in coal: an XAFS spectroscopic investigation. Fuel, 74 (4), 556-569

Jenkins, B.M., Baxter, L.L., Miles Jr., T.R., Miles, T.R., 1998. Combustion properties of biomass. Fuel Processing Technology, 54, 17-46

Jensen, P.A., Sander, B., Dam-Johansen, K., 2001. Removal of K and Cl by leaching of straw char. Biomass and Bioenergy, 20, 447-457 
Malkow, T., 2004. Novel and innovative pyrolysis and gasification technologies for energy efficient and environmentally sound MSW disposal. Waste management, 24, 53-79

Miranda, R., Yang, J., Roy, C., Vasile, C., 1999. Vacuum pyrolysis of PVC. I. Kinetic study. Polymer degradation and stability, 64, 127-144

Suryavanishi, A.K., Swamy, R.N., 1996. Stability of Friedel's salt in carbonated concrete structural elements. Cement and Concrete Research, 26 (5), 729-741

Vassilev, S.V., Braekman-Danheux, C., Laurent, P., 1999a. Characterization of refusederived char from municipal solid waste. 1. Phase-mineral and chemical composition. Fuel processing technology, 59, 95-134

Vassilev, S.V., Braekman-Danheux, C., Laurent, Ph., Thiemann, T., Fontana, A., 1999 b. Behavior, capture and inertization of some trace elements during combustion of refuse-derived char from municipal solid waste. Fuel, 78, 1131-1145

Watanabe, N., Tanigawa, N., Oikawa, T., Inoue, S., Fukuyama, J., 2003. Improved quartz furnace method for chlorine and sulfur determination in municipal solid waste. Journal of Material Cycle and Waste Management, 5 (1), 69-76 


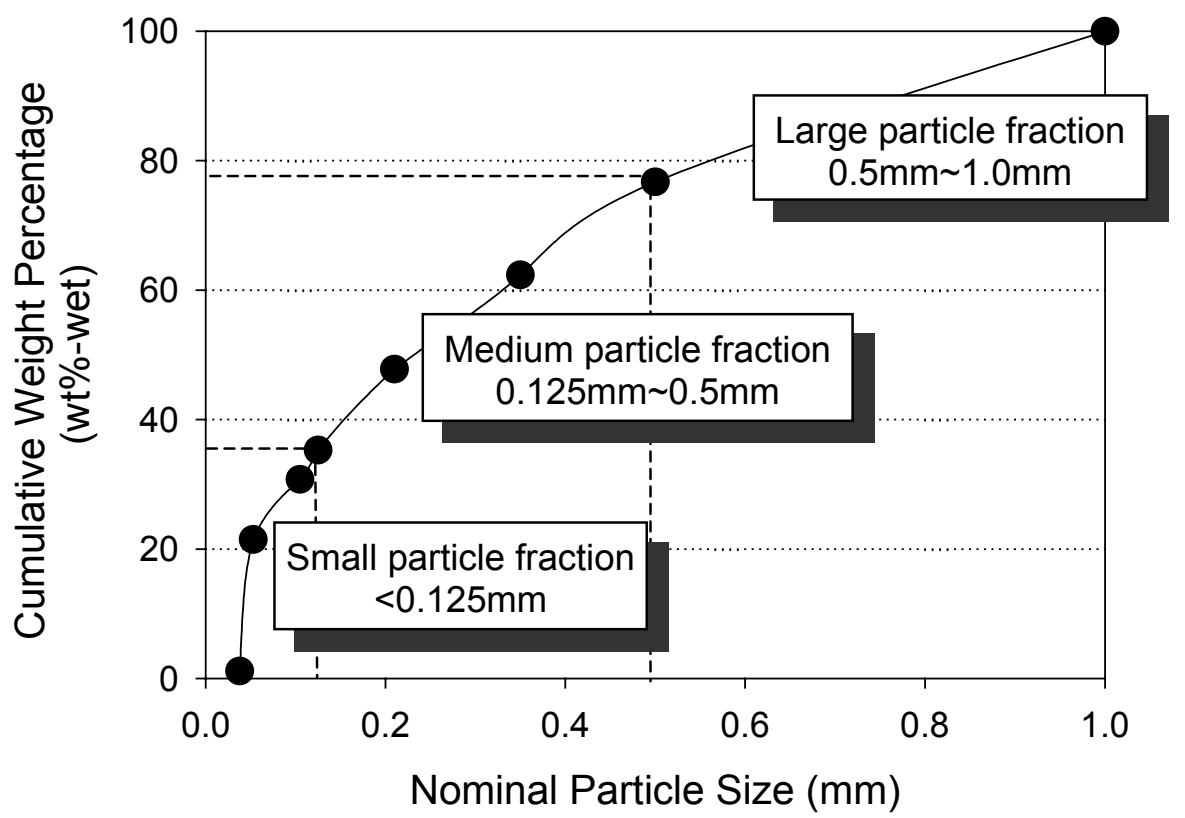

Fig. 1. Cumulative particle size distribution of char. 


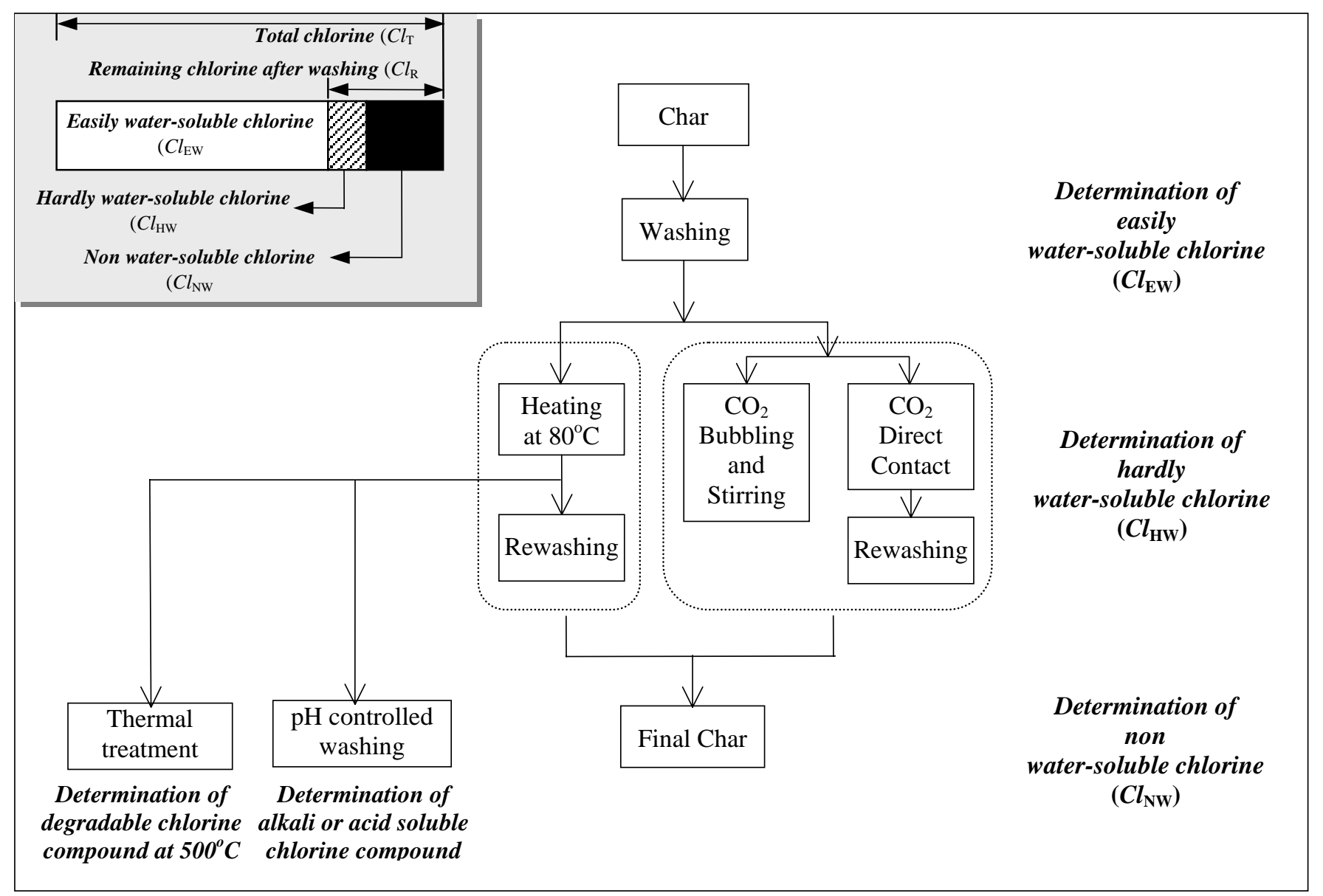

Fig. 2. Experimental flow for determination of chlorine in char based on water-solubility. 


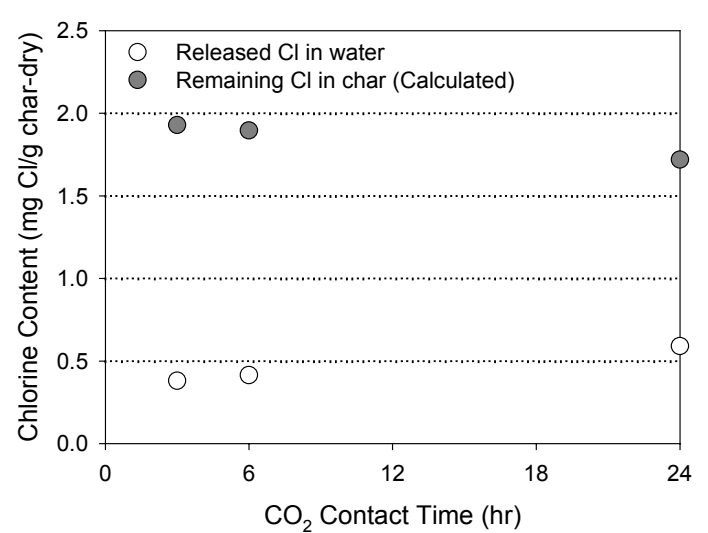

(a)

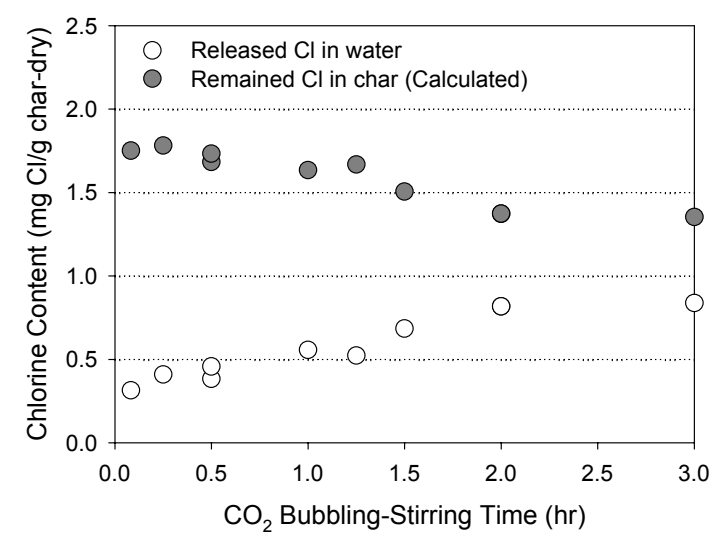

(b)

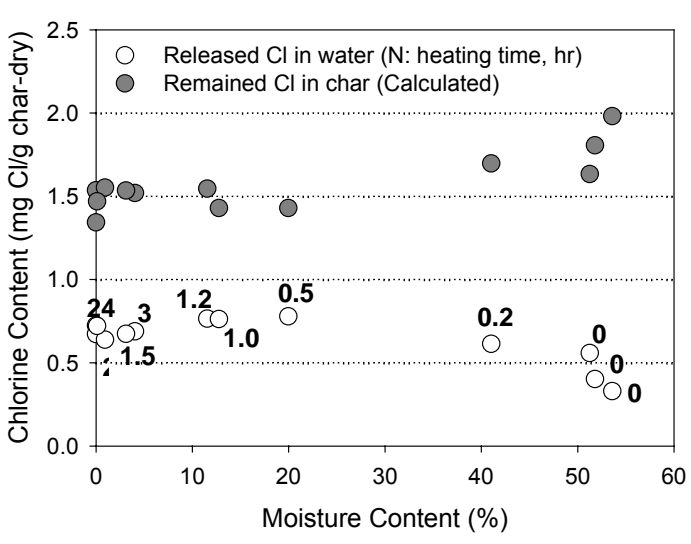

(c)

Fig. 3. Variation of released and remaining chlorine content in the condition of (a) $\mathrm{CO}_{2}$ direct contact and rewashing (method I),

(b) $\mathrm{CO}_{2}$ bubbling and stirring (method II), and (c) heating at $80^{\circ} \mathrm{C}$ and rewashing (method III). 


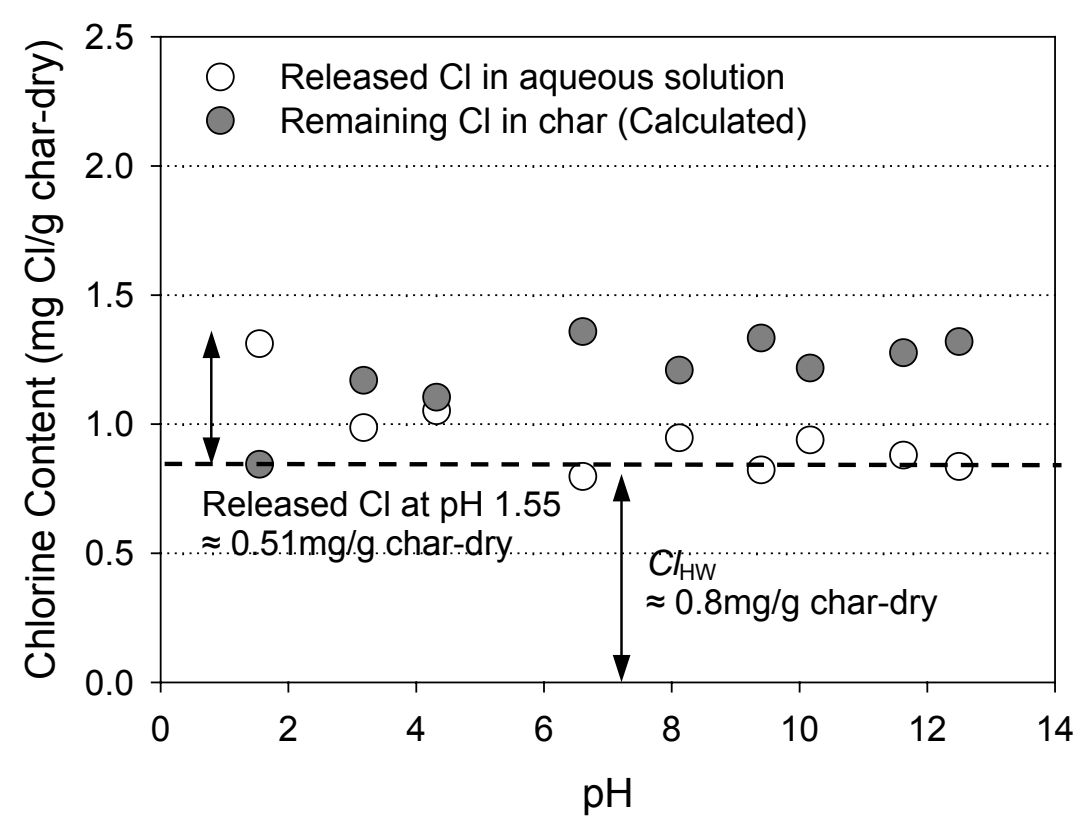

Fig. 4. Variation of released and remaining chlorine content according to $\mathrm{pH}$ of aqueous solution. 


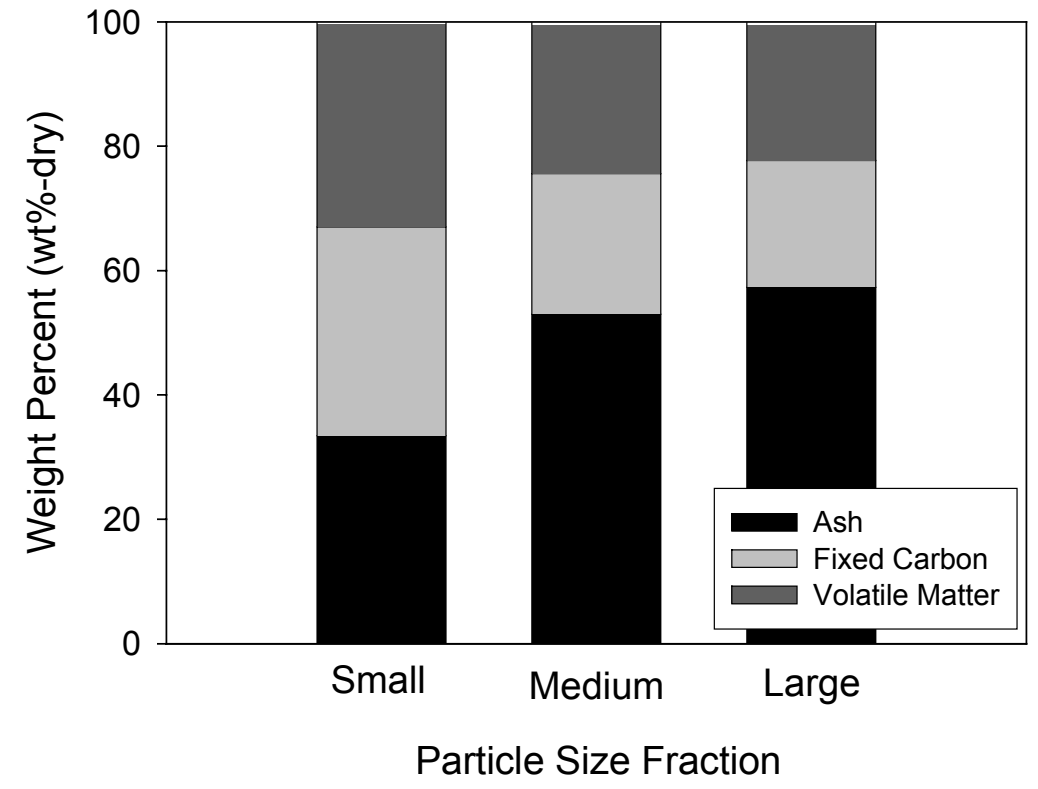

Fig. 5. Proximate analysis of char according to particle size fraction. 
Table 1

Total chlorine content of reference sample determined by existing or modified JIS Z 7302-6 method

(unit: $\mathrm{mg} \mathrm{Cl} / \mathrm{g}$-dry)

\begin{tabular}{|c|c|c|c|c|c|c|}
\hline \multirow{2}{*}{ Run } & \multirow{2}{*}{$\begin{array}{c}\text { Theoretical } \\
\text { chlorine content }^{\mathrm{a}}\end{array}$} & \multicolumn{2}{|c|}{ Volatile $\mathrm{Cl}$} & \multirow{2}{*}{$\begin{array}{c}\text { Residual Cl } \\
\text { Residue } \\
{[3]}\end{array}$} & \multicolumn{2}{|c|}{ Total chlorine content $\left(\mathrm{Cl}_{\mathrm{T}}\right)$} \\
\hline & & $\begin{array}{c}\text { Absorption bottle } \\
{[1]}\end{array}$ & $\begin{array}{c}\text { Reactor wall } \\
{[2]}\end{array}$ & & $\begin{array}{l}\text { Existing JIS } \\
\text { method }^{\mathrm{b}}\end{array}$ & $\begin{array}{l}\text { Modified JIS } \\
\text { method }^{\mathrm{d}}\end{array}$ \\
\hline 1 & \multirow{2}{*}{587.5} & 294.0 & 74.8 & 194.7 & $\begin{array}{l}294.0 \\
(50.0)^{\mathrm{c}}\end{array}$ & $\begin{array}{l}563.5 \\
(95.9)\end{array}$ \\
\hline 2 & & 337.9 & 81.9 & 175.4 & $\begin{array}{l}337.9 \\
(57.5)\end{array}$ & $\begin{array}{c}595.2 \\
(101.3)\end{array}$ \\
\hline
\end{tabular}

${ }^{\mathrm{a}}=(0.15 \times 0.607+0.15 \times 0.568) \div 0.3 \times 1,000$, Composition and weight of reference sample: $\mathrm{PVC} 0.15 \mathrm{~g}+\mathrm{NaCl} 0.15 \mathrm{~g}=0.3 \mathrm{~g}$, Theoretical chlorine content of $\mathrm{PVC}$ and $\mathrm{NaCl}$ is $60.7 \mathrm{wt} \%$-dry and $56.8 \mathrm{wt} \%$-dry respectively.; ${ }^{\mathrm{b}}=[1] ;{ }^{\mathrm{c}}(\mathrm{)})$ : Chlorine recovery ratio, $\% ;{ }^{\mathrm{d}}=[1]+[2]+[3]$ 
Table 2

Easily water-soluble chlorine $\left(C l_{\mathrm{EW}}\right)$ and remaining chlorine in char $\left(C l_{\mathrm{R}}\right)$ after a four-cycle of water-washing and filtering procedure (unit: $\mathrm{mg} \mathrm{Cl} / \mathrm{g}$ char-dry)

\begin{tabular}{|c|c|c|c|c|c|c|c|c|c|}
\hline & \multicolumn{5}{|c|}{ Easily water-soluble chlorine } & \multicolumn{3}{|c|}{ Remaining chlorine in washed char } & \multirow[b]{2}{*}{$\begin{array}{l}\text { Chlorine } \\
\text { content }^{\mathrm{c}}\end{array}$} \\
\hline & $\begin{array}{c}1^{\text {st }} \\
\text { washing }\end{array}$ & $\begin{array}{c}2^{\text {nd }} \\
\text { washing }\end{array}$ & $\begin{array}{c}3^{\text {rd }} \\
\text { washing }\end{array}$ & $\begin{array}{c}4^{\text {th }} \\
\text { washing }\end{array}$ & $\begin{array}{c}\text { Sum } \\
\left(C l_{\mathrm{EW}}\right) \\
{[1]}\end{array}$ & $\begin{array}{c}\text { Volatile } \\
\mathrm{Cl}\end{array}$ & $\begin{array}{c}\text { Residual } \\
\mathrm{Cl}\end{array}$ & $\begin{array}{c}\text { Sum } \\
\left(C l_{R}\right) \\
{[2]}\end{array}$ & \\
\hline Average $^{a}$ & 10.95 & 1.32 & 0.37 & 0.18 & 12.82 & 1.55 & 0.65 & 2.20 & 15.02 \\
\hline STDEV $^{\mathrm{b}}$ & 0.25 & 0.06 & 0.13 & 0.04 & 0.37 & 0.18 & 0.16 & 0.08 & 0.34 \\
\hline
\end{tabular}

${ }^{\mathrm{a}} n=6 ;{ }^{\mathrm{b}}$ Standard deviation; ${ }^{\mathrm{c}}=[1]+[2]$ 
Table 3

Released hardly water-soluble chlorine by method I, II, and III

(unit : $\mathrm{mg} \mathrm{Cl} / \mathrm{g}$ char-dry)

\begin{tabular}{cccc}
\hline Method & Experimental condition & $\begin{array}{c}\text { Easily water-soluble chlorine } \\
\left(\mathrm{Cl}_{\mathrm{EW}}\right)\end{array}$ & $\begin{array}{c}\text { Released hardly water-soluble } \\
\text { chlorine by method I, II, and III }\end{array}$ \\
\hline I & $\mathrm{CO}_{2}$ contact time $=24 \mathrm{hr}$ & 12.67 & 0.59 \\
II & $\mathrm{CO}_{2}$ bubbling time $=2 \sim 3 \mathrm{hr}$ \\
III & $\begin{array}{c}\text { Moisture content } \leq 20 \% \\
\text { Heating time } \geq 0.5 \mathrm{hr}\end{array}$ & 12.84 & 0.83 \\
\hline
\end{tabular}


Table 4

Chlorine balance in char based on water-solubility

(unit: $\mathrm{mg} \mathrm{Cl} / \mathrm{g}$ char-dry)

\begin{tabular}{|c|c|c|c|c|c|}
\hline \multirow{2}{*}{$\begin{array}{l}\text { Easily water-soluble } \\
\text { chlorine }^{\text {a }} \\
\left(C l_{\mathrm{EW}}\right) \\
{[1]}\end{array}$} & \multirow{2}{*}{$\begin{array}{l}\text { Hardly water-soluble } \\
\text { chlorine } \\
\left(\mathrm{Cl}_{\mathrm{HW}}\right) \\
{[2]}\end{array}$} & \multicolumn{3}{|c|}{ Non water-soluble chlorine } & \multirow[b]{2}{*}{$\begin{array}{c}\text { Total } \\
\text { Chlorine }\end{array}$} \\
\hline & & $\begin{array}{c}\text { Volatile } \\
\mathrm{Cl}\end{array}$ & $\begin{array}{c}\text { Residual } \\
\mathrm{Cl}\end{array}$ & $\begin{array}{c}\text { Sum } \\
\left(C l_{\mathrm{NW}}\right) \\
{[3]}\end{array}$ & \\
\hline 13.03 & 0.71 & 1.07 & 0.61 & 1.68 & 15.42 \\
\hline
\end{tabular}

${ }^{\mathrm{a}, \mathrm{b}}$ Data from Table 3 (Method III); ${ }^{\mathrm{c}}=[1]+[2]+[3]$ 
Table 5

Chlorine content of washed char before and after thermal treatment at $500^{\circ} \mathrm{C}$

(unit: $\mathrm{mg} \mathrm{Cl} / \mathrm{g}$ char-dry)

\begin{tabular}{|c|c|c|c|c|c|c|}
\hline \multirow{2}{*}{ Run No. } & \multicolumn{3}{|c|}{ Before thermal treatment ${ }^{\mathrm{a}}$} & \multicolumn{3}{|c|}{ After thermal treatment } \\
\hline & $\begin{array}{c}\text { Volatile } \\
\mathrm{Cl}\end{array}$ & $\begin{array}{c}\text { Residual } \\
\mathrm{Cl}\end{array}$ & $\begin{array}{l}\text { Sum } \\
\left(C l_{R}\right)\end{array}$ & $\begin{array}{c}\text { Volatile } \\
\mathrm{Cl}\end{array}$ & $\begin{array}{c}\text { Residual } \\
\mathrm{Cl}\end{array}$ & $\begin{array}{l}\text { Sum } \\
\left(C l_{R}\right)\end{array}$ \\
\hline 1 & \multirow{2}{*}{1.55} & \multirow{2}{*}{0.65} & \multirow{2}{*}{2.20} & 1.76 & 0.56 & 2.32 \\
\hline 2 & & & & 1.55 & 0.94 & 2.49 \\
\hline
\end{tabular}

${ }^{a}$ Data from Table 2 
Table 6

Total chlorine content and chlorine distribution based on water-solubility according to each particle size fraction

(unit: $\mathrm{mg} \mathrm{Cl} / \mathrm{g}$ char-dry)

\begin{tabular}{|c|c|c|c|c|c|c|c|c|}
\hline \multirow{2}{*}{$\begin{array}{c}\text { Sample }^{\mathrm{a}} \\
\text { (Particle size) }\end{array}$} & \multirow{2}{*}{$\begin{array}{l}\text { Total } \\
\text { chlorine } \\
\left(C l_{\mathrm{T}}\right)\end{array}$} & \multicolumn{5}{|c|}{ Easily water-soluble chlorine } & \multirow{2}{*}{$\begin{array}{l}\text { Hardly water- soluble } \\
\text { chlorine }^{\mathrm{c}} \\
\left(C l_{\mathrm{HW}}\right)\end{array}$} & \multirow{2}{*}{$\begin{array}{l}\text { Non water-soluble } \\
\text { chlorine }^{\mathrm{d}} \\
\left(C l_{\mathrm{NW}}\right)\end{array}$} \\
\hline & & $1^{\text {st }}$ & $2^{\text {nd }}$ & $3^{\text {rd }}$ & $4^{\text {th }}$ & $\begin{array}{c}\text { Sum } \\
\left(C l_{\mathrm{EW}}\right)\end{array}$ & & \\
\hline Large $(0.5 \sim 1.0 \mathrm{~mm})$ & 12.79 & $\begin{array}{c}7.76 \\
(0.53)^{b}\end{array}$ & $\begin{array}{c}1.42 \\
(0.06)\end{array}$ & $\begin{array}{c}0.40 \\
(0.03)\end{array}$ & $\begin{array}{c}0.21 \\
(0.03)\end{array}$ & $\begin{array}{c}9.79 \\
(0.62)\end{array}$ & $\begin{array}{c}0.76 \\
(0.26)\end{array}$ & $\begin{array}{c}2.24 \\
(0.37)\end{array}$ \\
\hline Medium (0.125 0.5mm) & 14.68 & $\begin{array}{c}9.99 \\
(0.55)\end{array}$ & $\begin{array}{c}1.45 \\
(0.07)\end{array}$ & $\begin{array}{c}0.34 \\
(0.02)\end{array}$ & $\begin{array}{c}0.16 \\
(0.01)\end{array}$ & $\begin{array}{l}11.94 \\
(0.48)\end{array}$ & $\begin{array}{c}0.96 \\
(0.25)\end{array}$ & $\begin{array}{c}1.78 \\
(0.69)\end{array}$ \\
\hline Small $(<0.125 \mathrm{~mm})$ & 15.21 & $\begin{array}{l}11.96 \\
(0.24)\end{array}$ & $\begin{array}{c}1.65 \\
(0.03)\end{array}$ & $\begin{array}{c}0.31 \\
(0.03)\end{array}$ & $\begin{array}{c}0.12 \\
(0.01)\end{array}$ & $\begin{array}{l}14.04 \\
(0.30)\end{array}$ & $\begin{array}{c}0.79 \\
(0.06)\end{array}$ & $\begin{array}{c}0.38 \\
(0.24)\end{array}$ \\
\hline
\end{tabular}

${ }^{\mathrm{a}} n=3 ;{ }^{\mathrm{b}}(\quad)$ : Standard deviation; ${ }^{\mathrm{c}}$ Determined by Method III (heating-rewashing method); ${ }^{\mathrm{d}}=\left[\mathrm{Cl}_{\mathrm{T}}\right]-\left[\mathrm{Cl}_{\mathrm{EW}}\right]-\left[\mathrm{Cl}_{\mathrm{HW}}\right]$ 
Table 7

Particle size distribution after milling of large particle fraction $(0.5 \mathrm{~mm} \sim 1.0 \mathrm{~mm})$ of char

\begin{tabular}{cc}
$\begin{array}{c}\text { Nominal aperture size } \\
(\mathrm{mm})\end{array}$ & $\begin{array}{c}\text { Cumulative weight percent } \\
\text { under nominal aperture size } \\
(\mathrm{wt} \% \text {-wet })\end{array}$ \\
\hline$\geq 1$ & 100.00 \\
1 & 99.84 \\
0.5 & 75.40 \\
0.35 & 66.90 \\
0.21 & 54.63 \\
0.125 & 41.22 \\
0.105 & 33.24 \\
0.053 & 1.25 \\
0.038 & 0.02 \\
\hline
\end{tabular}


Table 8

Chlorine balance in large particle fraction $(0.5 \mathrm{~mm} \sim 1.0 \mathrm{~mm})$ of char before and after pulverization

\begin{tabular}{|c|c|c|c|c|c|c|}
\hline \multirow[b]{2}{*}{ Sample } & \multirow{2}{*}{$\begin{array}{c}\text { Easily } \\
\text { water-soluble } \\
\text { chlorine } \\
\left(\mathrm{Cl}_{\mathrm{EW}}\right) \\
{[1]}\end{array}$} & \multirow{2}{*}{$\begin{array}{c}\text { Hardly } \\
\text { water-soluble } \\
\text { chlorine } \\
\left(\mathrm{Cl}_{\mathrm{HW}}\right) \\
{[2]}\end{array}$} & \multicolumn{3}{|c|}{ Non water-soluble chlorine } & \multirow{2}{*}{$\begin{array}{c}\text { Total } \\
\text { chlorine }^{\mathrm{a}}\end{array}$} \\
\hline & & & $\begin{array}{c}\text { Volatile } \\
\mathrm{Cl}\end{array}$ & $\begin{array}{c}\text { Residual } \\
\mathrm{Cl}\end{array}$ & $\begin{array}{c}\text { Sum } \\
\left(C l_{\mathrm{NW}}\right) \\
{[3]}\end{array}$ & \\
\hline Before pulverization & 9.78 & 0.76 & 1.58 & 1.02 & 2.60 & 13.14 \\
\hline After pulverization & 9.82 & 0.50 & 2.24 & 0.40 & 2.64 & 12.96 \\
\hline
\end{tabular}

$\bar{a}=[1]+[2]+[3]$ 
Table 9

Non water-soluble chlorine released from large particle fraction of char by $\mathrm{HNO}_{3}-\mathrm{HF}$ digestion (unit: $\mathrm{mg} \mathrm{Cl} / \mathrm{g}$ char-dry)

\begin{tabular}{|c|c|c|}
\hline $\begin{array}{c}\text { Remaining chlorine in char } \\
\text { before } \mathrm{HNO}_{3}-\mathrm{HF} \text { digestion } \\
\text { a }\end{array}$ & $\begin{array}{c}\text { Released chlorine from char } \\
\text { by } \mathrm{HNO}_{3} \text {-HF digestion } \\
\text { [2] }\end{array}$ & $\begin{array}{l}\text { Remaining chlorine in char } \\
\text { after } \mathrm{HNO}_{3} \text {-HF digestion }\end{array}$ \\
\hline \multirow{2}{*}{2.60} & 0.82 & 1.78 \\
\hline & $(0.03)^{\mathrm{c}}$ & $(0.03)$ \\
\hline
\end{tabular}

${ }^{\mathrm{a}}$ Data from Table $8 ;{ }^{\mathrm{b}} n=3 ;{ }^{\mathrm{c}}(\quad)$ : Standard deviation; ${ }^{\mathrm{d}}=[1]-[2]$ 